\title{
Synthesis and Characterisation of Zinc(II) Complex With 2-Amino-5-bromopyridine Ligand
}

\author{
Fitriani, Kanidtha Hansongnern ", Nararak Leesakul and Chaveng Pakawatchai \\ Department of Chemistry and Center for Innovation in Chemistry, Faculty of Science, \\ Prince of Songkla University, Hat Yai, Songkhla 90112, Thailand \\ *Correspondence e-mail: kanidtha.h@psu.ac.th
}

\begin{abstract}
The synthesis and characterisation of zinc(II) complex with 2-amino-5-bromopyridine $\left(\mathrm{C}_{5} \mathrm{H}_{5} \mathrm{BrN}_{2}\right)$ ligand have been described. The complex was structurally characterised via $\mathrm{X}$-ray crystallography, in the title compound, (2-amino-5-bromopyridinium) $\left[\mathrm{ZnCl}_{3}\right.$ (2-amino5-bromopyridine)] or which is also called $\left(\mathrm{C}_{5} \mathrm{H}_{6} \mathrm{BrN}_{2}\right)\left[\mathrm{ZnCl}_{3}\left(\mathrm{C}_{5} \mathrm{H}_{5} \mathrm{BrN}_{2}\right)\right]$. The $\mathrm{Zn}(\mathrm{II})$ atom is four-coordinated by three $\mathrm{Cl}$ atoms and one imine $\mathrm{N}$-atom of 2-amino-5-bromopyridine ligand, forming a distorted tetrahedral coordination geometry. The complex was also investigated by elemental analysis, ${ }^{1} \mathrm{H}$ NMR, IR spectroscopy and UV-Visible absorption. The protonation behaviour upon coordination is discussed.
\end{abstract}

Keywords: molecular structure, single crystal, coordination geometry, protonation

Poster presentation

Oral presentation 
Poster presentation

Oral presentation

\title{
Synthesis and Characterisation of Zinc(II) Complex With 2-Amino-5-bromopyridine Ligand
}

\author{
Fitriani, Kanidtha Hansongnern ", Nararak Leesakul and Chaveng Pakawatchai \\ Department of Chemistry and Center for Innovation in Chemistry, Faculty of Science, \\ Prince of Songkla University, Hat Yai, Songkhla 90112, Thailand \\ *Correspondence e-mail: kanidtha.h@psu.ac.th
}

\begin{abstract}
The synthesis and characterisation of zinc(II) complex with 2-amino-5-bromopyridine $\left(\mathrm{C}_{5} \mathrm{H}_{5} \mathrm{BrN}_{2}\right)$ ligand have been described. The complex was structurally characterised via $\mathrm{X}$-ray crystallography, in the title compound, (2-amino-5-bromopyridinium) $\left[\mathrm{ZnCl}_{3}\right.$ (2-amino5-bromopyridine)] or which is also called $\left(\mathrm{C}_{5} \mathrm{H}_{6} \mathrm{BrN}_{2}\right)\left[\mathrm{ZnCl}_{3}\left(\mathrm{C}_{5} \mathrm{H}_{5} \mathrm{BrN}_{2}\right)\right]$. The $\mathrm{Zn}(\mathrm{II})$ atom is four-coordinated by three $\mathrm{Cl}$ atoms and one imine $\mathrm{N}$-atom of 2-amino-5-bromopyridine ligand, forming a distorted tetrahedral coordination geometry. The complex was also investigated by elemental analysis, ${ }^{1} \mathrm{H}$ NMR, IR spectroscopy and UV-Visible absorption. The protonation behaviour upon coordination is discussed.
\end{abstract}

Keywords: molecular structure, single crystal, coordination geometry, protonation

\section{INTRODUCTION}

Heterocyclic compounds analogues and derivatives have received considerable interest in the last many years due to their ability to coordinate to metal ions and known to have various chemical and biological properties. Pyridine is a type of heterocyclic organic compound with the chemical formula $\mathrm{C}_{5} \mathrm{H}_{5} \mathrm{~N}$. It is structurally related to benzene, with one $\mathrm{CH}$ group replaced by a nitrogen atom. In recent years, pyridine and its derivatives are found to be suitable ligands for transition metal coordination compounds involving $\mathrm{Fe}(\mathrm{II})$; $\mathrm{Ni}(\mathrm{II})$ [1], $\mathrm{Cu}$ (II) ; $\mathrm{Co}(\mathrm{II})$ [2] and $\mathrm{Zn}$ (II) [3]. Several pyridine derivatives play important roles in biological properties such as antifungal and antibacterial activities [4] as well as electrochemical properties [5].

The 2-amino-5-bromopyridine is one of the pyridine derivatives, used to form the metal complex, which has an ortho substituent next to the $\mathrm{N}$ atom and para position with respect to the amino substituent. In an attempt to prepare the metal complex of this type, we present here the synthesis and X-ray crystal structure of zinc(II) chloride with 2-amino-5bromopyridine, which is a monodentate Ndonor ligand. The spectroscopic properties of the compound and the X-ray crystal structure of zinc(II) complex are also presented and discussed. 


\section{MATERIALS AND METHODS}

\section{Raw Material}

2-amino-5-bromopyridine, $\mathrm{C}_{5} \mathrm{H}_{5} \mathrm{BrN}_{2}$ A.R. grade and zinc(II) chloride, $\mathrm{ZnCl}_{2} \mathrm{~L}$. $\mathrm{R}$ grade were purchased from Aldrich Chemical Company and Fisher Scientific Company, respectively. All chemicals and solvents were purchased as A.R. grade products and were used without further purification.

\section{Sample Preparation}

The $\left(\mathrm{C}_{5} \mathrm{H}_{6} \mathrm{BrN}_{2}\right) \quad\left[\mathrm{ZnCl}_{3}\left(\mathrm{C}_{5} \mathrm{H}_{5} \mathrm{BrN}_{2}\right)\right]$ complex was prepared by direct reaction between zinc(II) chloride, $\mathrm{ZnCl}_{2}$ with 2amino-5-bromopyridine, $\mathrm{C}_{5} \mathrm{H}_{5} \mathrm{BrN}_{2}$ under suitable condition. The colourless needle crystals of the complex were obtained from the filtrate after keeping to evaporate at room temperature. The $\left(\mathrm{C}_{5} \mathrm{H}_{6} \mathrm{BrN}_{2}\right)$ $\left[\mathrm{ZnCl}_{3}\left(\mathrm{C}_{5} \mathrm{H}_{5} \mathrm{BrN}_{2}\right)\right]$ complex was characterised using elemental analysis ${ }^{1} \mathrm{H}$ NMR, IR spectroscopy and UV-Visible absorption. The crystal structure of zinc(II) complex was determined by means of X-ray single crystal diffraction analysis. The cell parameters and diffraction data of zinc(II) complex were performed at room temperature on Bruker APEX CCD diffractometer. The Shelx program was used for solving and refining the crystal structure.

The elemental analysis data of the complex were given as follow. $\left(\mathrm{C}_{5} \mathrm{H}_{6} \mathrm{BrN}_{2}\right)$ $\left[\mathrm{ZnCl}_{3}\left(\mathrm{C}_{5} \mathrm{H}_{5} \mathrm{BrN}_{2}\right)\right]$ Yield (440 mg; $28 \%$ ). m.p: $188-190{ }^{\circ} \mathrm{C}$. Anal. Calcd. for $\left(\mathrm{C}_{5} \mathrm{H}_{6} \mathrm{BrN}_{2}\right) \quad\left[\mathrm{ZnCl}_{3}\left(\mathrm{C}_{5} \mathrm{H}_{5} \mathrm{BrN}_{2}\right)\right]: \mathrm{C}, 23.15$; $\mathrm{H}, 2.14 ; \mathrm{N}, 10.80 \%$. Found: C, 23.31; H, $2.09 ; \mathrm{N}, 10.64 \%$.

\section{RESULTS}

\section{X-ray crystallography}

Table 1. Summarised crystallographic data for $\left(\mathrm{C}_{5} \mathrm{H}_{6} \mathrm{BrN}_{2}\right)\left[\mathrm{ZnCl}_{3}\left(\mathrm{C}_{5} \mathrm{H}_{5} \mathrm{BrN}_{2}\right)\right]$ complex.

Empirical formula
Formula weight
Temperature
Wavelength
Crystal system
Space group
Unit cell dimensions

Volume

$Z$

Density (calculated)

Absorption coefficient

$F(000)$

Crystal size

Theta range for data collection

Index ranges

Reflections collected

Independent reflections

Completeness to theta $=25.00^{\circ}$

Absorption correction

Max. and min. transmission

Refinement method
$\mathrm{C}_{10} \mathrm{H}_{11} \mathrm{Br}_{2} \mathrm{Cl}_{3} \mathrm{~N}_{4} \mathrm{Zn}$

518.77

293(2) K

$0.71073 \AA$

Monoclinic

$P 2_{1} / n$

$\begin{array}{ll}a=9.4238(4) \AA & \alpha=90^{\circ} \\ b=13.6544(6) \AA & \beta=104\end{array}$

$b=13.6544(6) \AA \quad \beta=104.3490(10)^{\circ}$

$c=13.5679(6) \AA \quad \alpha=90^{\circ}$

1691.40(13) $\AA^{3}$

4

$2.037 \mathrm{Mg} / \mathrm{m}^{3}$

$6.644 \mathrm{~mm}^{-1}$

1000

$0.257 \times 0.162 \times 0.083 \mathrm{~mm}^{3}$

2.15 to $25.00^{\circ}$

$-11<=\mathrm{h}<=11,-16<=\mathrm{k}<=16,-16<=\mathrm{l}<=16$

18043

$2979[R(\mathrm{int})=0.0335]$

$100.0 \%$

Semi-empirical from equivalents

1.000 and 0.664

Full-matrix least-squares on $F^{2}$ 
Data / restraints / parameters

Goodness-of-fit on $F^{2}$

Final $R$ indices $[I>2 \square(I)]$

$R$ indices (all data)

Largest diff. peak and hole

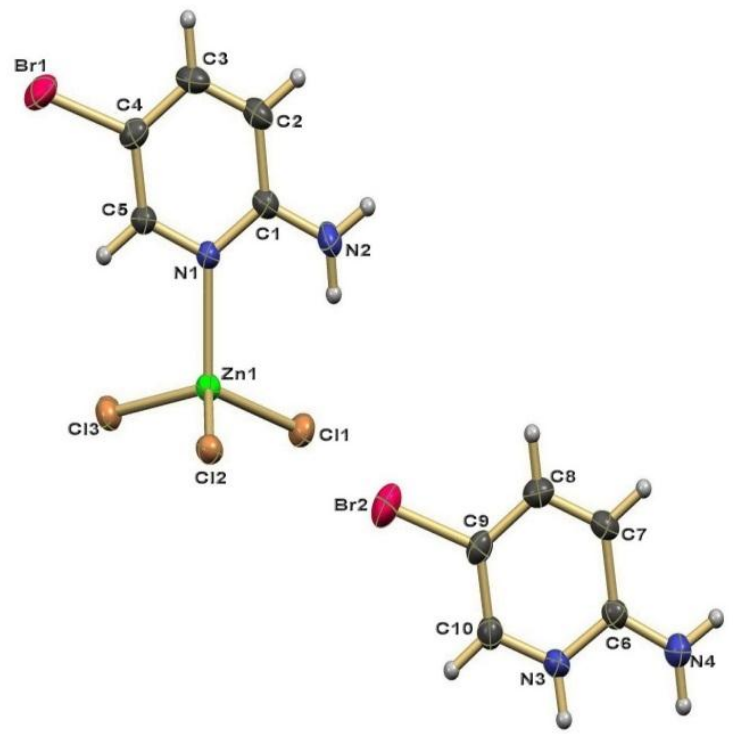

Figure 1. The structure of

$\left(\mathrm{C}_{5} \mathrm{H}_{6} \mathrm{BrN}_{2}\right)\left[\mathrm{ZnCl}_{3}\left(\mathrm{C}_{5} \mathrm{H}_{5} \mathrm{BrN}_{2}\right)\right]$

showing the atom numbering scheme.

\section{DISCUSSION}

\section{Structural description of zinc(II) complex $\left(\mathrm{C}_{5} \mathrm{H}_{6} \mathrm{BrN}_{2}\right)\left[\mathrm{ZnCl}_{3}\left(\mathrm{C}_{5} \mathrm{H}_{5} \mathrm{BrN}_{2}\right)\right]$}

The asymmetric unit of this complex consists of discrete $\left[\mathrm{ZnCl}_{3}\left(\mathrm{C}_{5} \mathrm{H}_{5} \mathrm{BrN}_{2}\right)\right]^{-}$ complex anion and $\left[\mathrm{C}_{5} \mathrm{H}_{6} \mathrm{BrN}_{2}\right]^{+}$cation. The $\mathrm{Zn}$ (II) atom in the $\left[\mathrm{ZnCl}_{3}\left(\mathrm{C}_{5} \mathrm{H}_{5} \mathrm{BrN}_{2}\right)\right]^{-}$ complex anion is coordinated by three $\mathrm{Cl}$ atoms and one imine $\mathrm{N}$-atom of 2-amino-5bromopyridine ligand, within a distorted tetrahedral coordination environment. Moreover, the protonated form of pyridine nitrogen atom of a 2-amino-5bromopyridine ligand is observed.

The protonated $\mathrm{N}$-atom of pyridinium ring and the amino group of the cation are linked to the $\mathrm{Zn}$ (II) complex anion, via inter- and intra-molecular $\mathrm{N}-\mathrm{H}^{\cdots \cdots} \mathrm{Cl}$ hydrogen bonds. A perspective view of the asymmetric unit of the complex with the atom numbering scheme is depicted in Figure 1. Crystal data and structure
2979 / 5 / 196

1.024

$R 1=0.0334, w R 2=0.0813$

$R 1=0.0423, w R 2=0.0861$

1.230 and -0.397 e. $^{-3}$

refinement for the complex are summarised in Table 1.

\section{NMR Spectra}

The ${ }^{1} \mathrm{H}$ NMR spectra of the zinc(II) complex was recorded in DMSO- $d_{6}$ as solvent, occurs at $\delta=6.68 \mathrm{ppm}-6.70 \mathrm{ppm}$ as doublet, $\delta=7.77 \mathrm{ppm}-7.79 \mathrm{ppm}$ as doublet of doublet (dd), and $\delta=8.09 \mathrm{ppm}-$ $8.10 \mathrm{ppm}$ as doublet peak. Meanwhile, the existence of the complex in the protonated form is confirmed by the disappearance of the signal from the amino group whereas the nitrogen atom of the 2-amino-5bromopyridine ligand is protonated upon complexation. As the result the protonation of nitrogen atom in zinc(II) complex $\left(\mathrm{C}_{5} \mathrm{H}_{6} \mathrm{BrN}_{2}\right)\left[\mathrm{ZnCl}_{3}\left(\mathrm{C}_{5} \mathrm{H}_{5} \mathrm{BrN}_{2}\right)\right]$ is observed and which is also evident from $\mathrm{X}$-ray result (Figure 1). However, the differences of chemical shift of pyridine $\mathrm{H}$ atoms indicate that the $\mathrm{N}$ atom of pyridine coordinate to the metal ion [6].

\section{IR Spectra}

The IR spectra of the free ligand 2amino-5-bromopyridine shows the characteristic bands at $3453 \mathrm{~cm}^{-1}$ and 3293 $\mathrm{cm}^{-1}, 1623 \mathrm{~cm}^{-1}$ and $1591 \mathrm{~cm}^{-1}, 1474 \mathrm{~cm}^{-1}$, $1387 \mathrm{~cm}^{-1}, 515 \mathrm{~cm}^{-1}$, assignable to $v\left(\mathrm{NH}_{2}\right)$, $v(\mathrm{C}=\mathrm{C}), \quad v(\mathrm{C}=\mathrm{N}), \quad v(\mathrm{C}-\mathrm{N}), \quad v(\mathrm{C}-\mathrm{Br})$ stretching modes, respectively. Meanwhile in $\left(\mathrm{C}_{5} \mathrm{H}_{6} \mathrm{BrN}_{2}\right)\left[\mathrm{ZnCl}_{3}\left(\mathrm{C}_{5} \mathrm{H}_{5} \mathrm{BrN}_{2}\right)\right]$ complex, the characteristic bands of pyridine occur at $1636 \mathrm{~cm}^{-1}$ and $1609 \mathrm{~cm}^{-1}, 1498 \mathrm{~cm}^{-1}$, $1332 \mathrm{~cm}^{-1}, 500 \mathrm{~cm}^{-1}$, assigned for $v(\mathrm{C}=\mathrm{C})$, $v(\mathrm{C}=\mathrm{N}), v(\mathrm{C}-\mathrm{N}), v(\mathrm{C}-\mathrm{Br})$ stretching modes, respectively. The appearance of the band in the strong intensity at $456 \mathrm{~cm}^{-1}$ due to $v(\mathrm{Zn}-\mathrm{Cl})$ stretching vibration while the band at $533 \mathrm{~cm}^{-1}$ is attributed to $v(\mathrm{Zn}-\mathrm{N})$ stretching vibration. The coordination of the nitrogen atom to metal ion is confirmed with the presence of this band [7]. 
Table 2. ${ }^{1} \mathrm{H}$ NMR spectral data of

$\left(\mathrm{C}_{5} \mathrm{H}_{6} \mathrm{BrN}_{2}\right)\left[\mathrm{ZnCl}_{3}\left(\mathrm{C}_{5} \mathrm{H}_{5} \mathrm{BrN}_{2}\right)\right]$ complex.

\begin{tabular}{|c|c|c|c|}
\hline \multirow{2}{*}{$\underset{\text { position }}{\mathrm{H}-}$} & ${ }^{1} \mathrm{H}$ NMR & spectral & data \\
\hline & $\delta(\mathrm{ppm})$ & $\frac{\text { Amount of }}{\mathrm{H}}$ & Peak \\
\hline $3,3^{\prime}$ & $6.68-6.70$ & 2 & $\mathrm{~d}$ \\
\hline $4,4^{\prime}$ & $7.77-7.79$ & 2 & $\mathrm{dd}$ \\
\hline $6,6^{\prime}$ & $8.09-8.10$ & 2 & $\mathrm{~d}$ \\
\hline
\end{tabular}

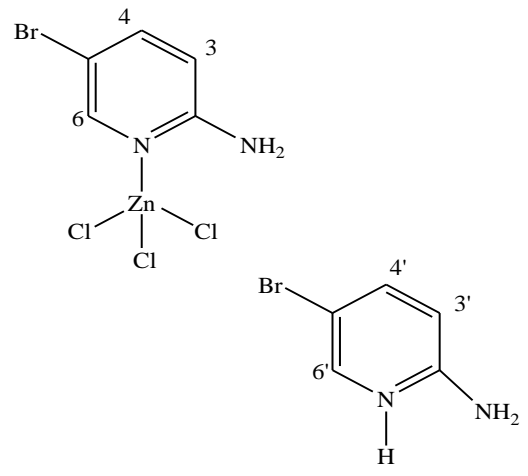

Figure 2. The molecular structure of $\left(\mathrm{C}_{5} \mathrm{H}_{6} \mathrm{BrN}_{2}\right)\left[\mathrm{ZnCl}_{3}\left(\mathrm{C}_{5} \mathrm{H}_{5} \mathrm{BrN}_{2}\right)\right]$ complex with proton numbering system.
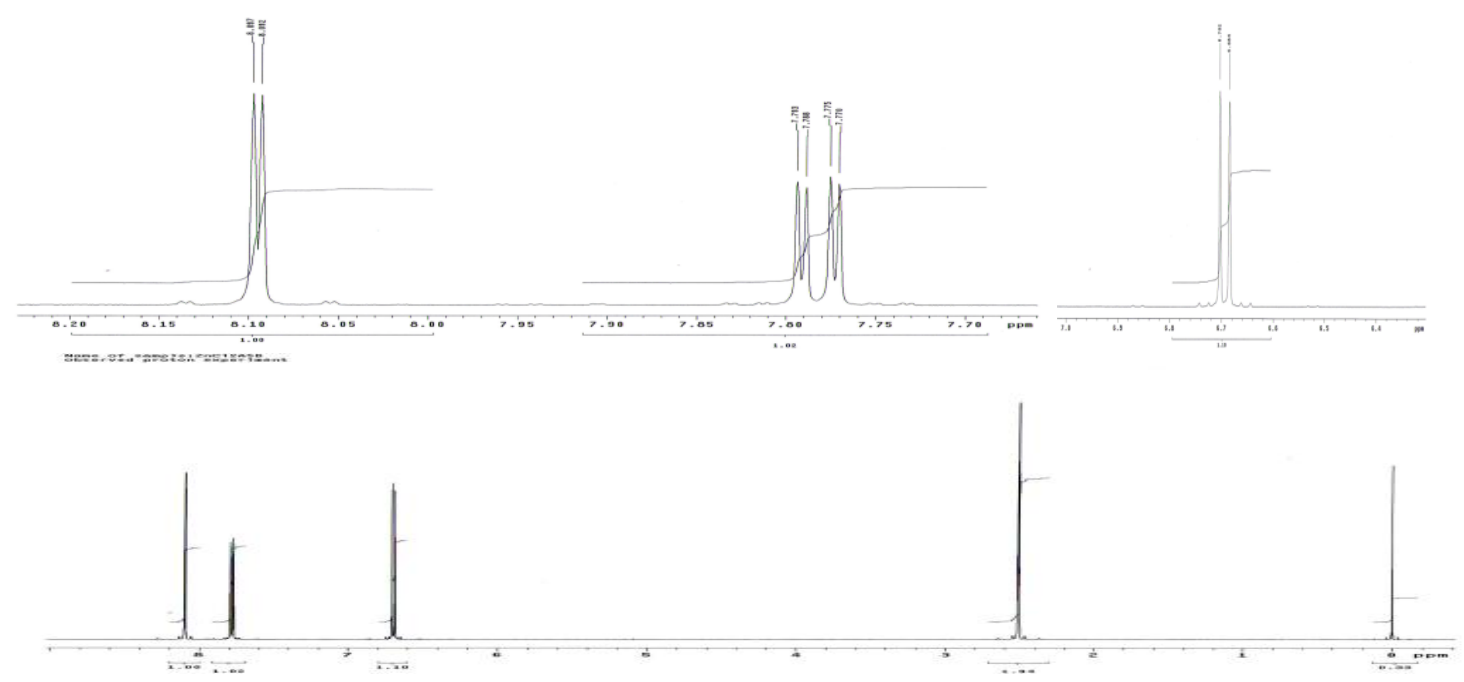

Figure 3. ${ }^{1} \mathrm{H}$ NMR spectrum of $\left(\mathrm{C}_{5} \mathrm{H}_{6} \mathrm{BrN}_{2}\right)\left[\mathrm{ZnCl}_{3}\left(\mathrm{C}_{5} \mathrm{H}_{5} \mathrm{BrN}_{2}\right)\right]$ complex in $\mathrm{DMSO}-d_{6}$ solvent.

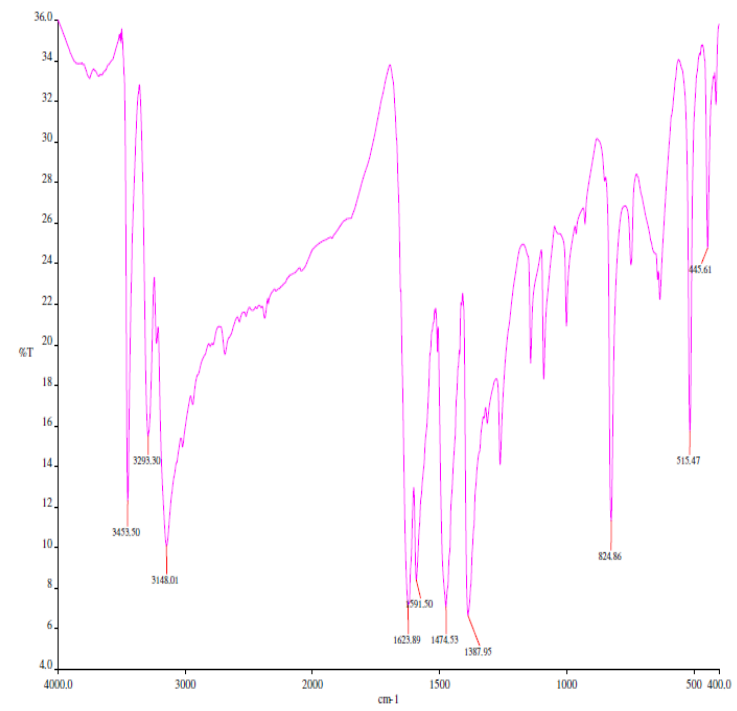

Figure 4. The infrared spectra of 2-amino-5-bromopyridine ligand.

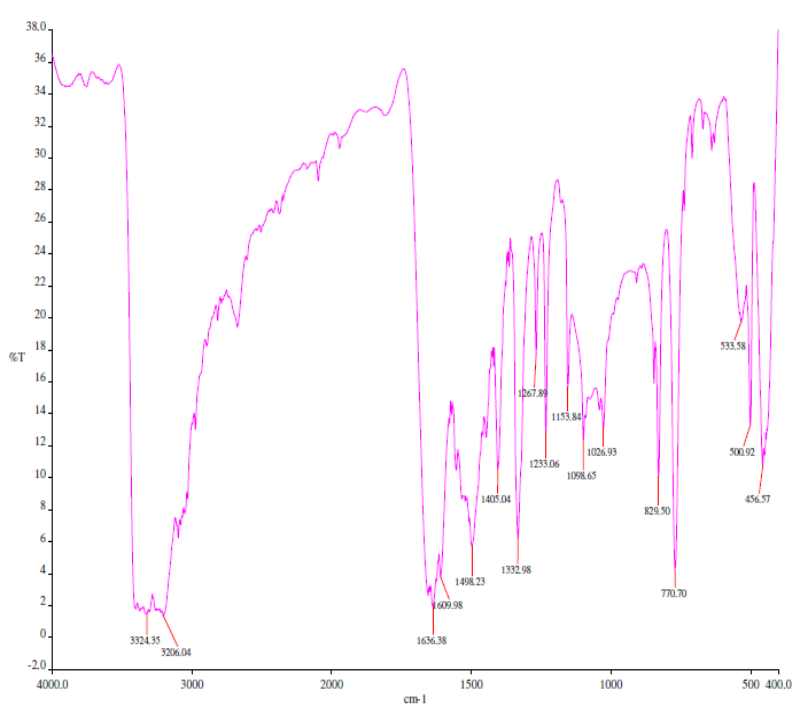

Figure 5. The infrared spectra of $\left(\mathrm{C}_{5} \mathrm{H}_{6} \mathrm{BrN}_{2}\right)\left[\mathrm{ZnCl}_{3}\left(\mathrm{C}_{5} \mathrm{H}_{5} \mathrm{BrN}_{2}\right)\right]$ complex. 


\section{UV-Visible Absorption Spectra}

The electronic spectra of the free ligand and its zinc(II) complex were recorded using Dimethyl Formalmide (DMF) as solvent in the region of 200-800 $\mathrm{nm}$ at ambient temperature. As can be seen from the Table 3 and Figure 6, show the comparison of the electronic spectra between the free ligand of 2-amino-5bromopyridine with zinc(II) complex, $\left(\mathrm{C}_{5} \mathrm{H}_{6} \mathrm{BrN}_{2}\right) \quad\left[\mathrm{ZnCl}_{3}\left(\mathrm{C}_{5} \mathrm{H}_{5} \mathrm{BrN}_{2}\right)\right]$. The electronic absorption data of the ligand exhibit two bands in the UV region. The band at $265 \mathrm{~nm}$ in the electronic spectra of the ligand is being assigned to $\pi \rightarrow \pi^{*}$ transition, while the band at $311 \mathrm{~nm}$ corresponds to charge - transfer $\left(\mathrm{n} \rightarrow \pi^{*}\right)$ transition from the lone pair electron of the $\mathrm{C}=\mathrm{N}$ group to the metal ion. In contrast to $\left(\mathrm{C}_{5} \mathrm{H}_{6} \mathrm{BrN}_{2}\right)\left[\mathrm{ZnCl}_{3}\left(\mathrm{C}_{5} \mathrm{H}_{5} \mathrm{BrN}_{2}\right)\right]$ complex, $\pi \rightarrow \pi^{*}$ transition has a little red shift compared to the free ligand at 268 $\mathrm{nm}$, confirming the ligand was coordinated to $\mathrm{Zn}(\mathrm{II})$ ion through nitrogen atom upon complexation [8].

Table 3. Electronic spectra of the free ligand and its zinc(II) complex in DMF solution.

\begin{tabular}{|c|c|}
\hline Compounds & UV-Visible Absorption $\lambda_{\max }(\mathrm{nm})$ \\
\hline 2-amino-5-bromopyridine ligand & $265 \mathrm{~nm}, 311 \mathrm{~nm}$ \\
\hline$\left(\mathrm{C}_{5} \mathrm{H}_{6} \mathrm{BrN}_{2}\right)\left[\mathrm{ZnCl}_{3}\left(\mathrm{C}_{5} \mathrm{H}_{5} \mathrm{BrN}_{2}\right)\right]$ complex & $268 \mathrm{~nm}$ \\
\hline
\end{tabular}

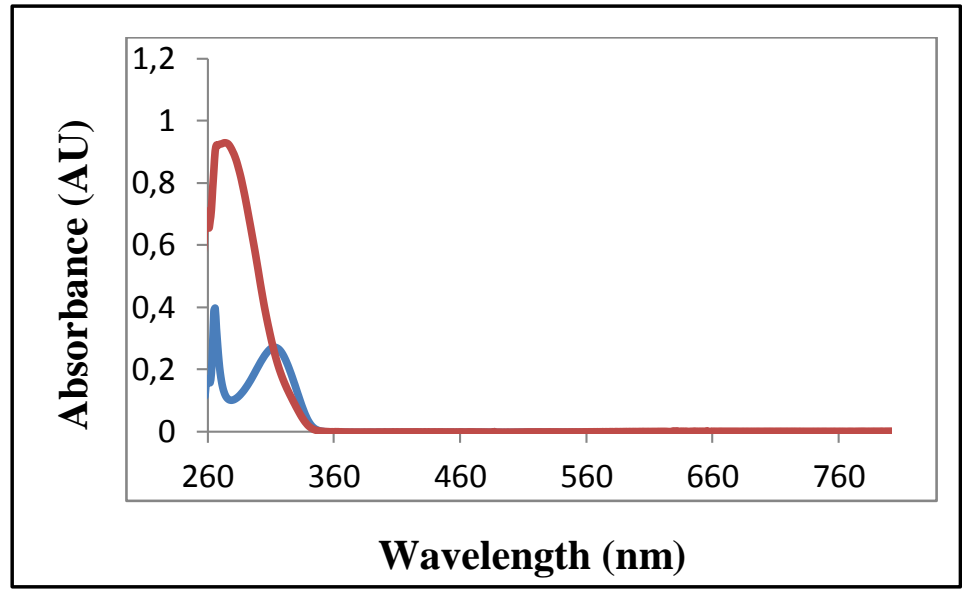

Figure 6. UV-Visible absorption spectra of the 2-amino-5-bromopyridine ligand and its zinc(II) complex $\left(\mathrm{C}_{5} \mathrm{H}_{6} \mathrm{BrN}_{2}\right)\left[\mathrm{ZnCl}_{3}\left(\mathrm{C}_{5} \mathrm{H}_{5} \mathrm{BrN}_{2}\right)\right]$ in DMF solution.

$\begin{array}{lll}\text { Remark : } \quad \longrightarrow & \text { 2-amino-5-bromopyridine ligand } \\ = & \left(\mathrm{C}_{5} \mathrm{H}_{6} \mathrm{BrN}_{2}\right)\left[\mathrm{ZnCl}_{3}\left(\mathrm{C}_{5} \mathrm{H}_{5} \mathrm{BrN}_{2}\right)\right] \text { complex }\end{array}$

\section{CONCLUSION}

In summary, determination of the crystal structure of zinc(II) complex by X-ray diffraction analysis shows a distorted tetrahedral coordination environment for $\left(\mathrm{C}_{5} \mathrm{H}_{6} \mathrm{BrN}_{2}\right) \quad\left[\mathrm{ZnCl}_{3}\left(\mathrm{C}_{5} \mathrm{H}_{5} \mathrm{BrN}_{2}\right)\right]$ complex. The $\mathrm{Zn}(\mathrm{II})$ atom in the $\left[\mathrm{ZnCl}_{3}\left(\mathrm{C}_{5} \mathrm{H}_{5} \mathrm{BrN}_{2}\right)\right]$ complex anion is coordinated by three $\mathrm{Cl}$ atoms and one imine $\mathrm{N}$-atom of 2-amino-5bromopyridine ligand. In addition, the pyridine $\mathrm{N}$-atom of 2-amino-5bromopyridine ligand is protonated. The elemental analysis and ${ }^{1} \mathrm{H}$ NMR technique confirmed the formula of the complex. Result from the elemental analysis showed that the calculated values of the complex was satisfactory when compared with the experimental values. Furthermore, the IR spectroscopy and UV-Visible absorption of the ligand and its zinc(II) complex were also studied and identified. 


\section{ACKNOWLEDGMENTS}

The work was supported financially by Department of Chemistry and Graduate School, Prince of Songkla University, Hat Yai, Thailand. One of the authors (Fitriani) is thankful to the Directorate General of Higher Education (DGHE) of Indonesia and Brawijaya University, Malang, Indonesia, for financial assistance and a DGHE postgraduate scholarship.

\section{REFERENCES}

[1] Hubrich, M., Peukert, M., Seichter, W and Weber, E. 2010. Complexes of 4and 5-bromo derivatives of 2(hydroxymethyl)pyridine with copper(II) and cobalt(II) salts. Synthesis and X-ray crystal structure. Polyhedron 29: $1854-1862$.

[2] Janiak, C., Deblon, S., Wu, H., Kolm, M.J., Klüfers, P., Piotrowski, $\mathrm{H}$ and Mayer, P. 1999. Modified Bipyridines: 5,59-Diamino-2,29-bipyridine Metal Complexes Assembled into Multidimensional Networks via Hydrogen Bonding and $\pi-\pi$ Stacking Interactions. Eur. J. Inorg. Chem 15071521.

[3] Wei, Z., Xie, X., Zhao, J., Huang, L and Liu, X. 2012. A novel hexadentate ligand and its complexes with divalent metal ions (Zinc, Copper, and Cobalt): Synthesis, characterization, and electrochemical Investigation. Inorganica Chimica Acta 387: 277-282.
[4] Bhatia, M.S., Mulani, A.K., Choudhari, P.B., Ingale, K.B and Bhatia, N.M. 2009. Synthesis and QSAR analysis of 5-substituted (arylmethylene)pyridin-2amine derivatives as potential antibacterials. International Journal of Drug Discovery 1: 1-9.

[5] Xiao, X.W., He, Y.J., Sun, L.W., Wang, G.N., Shen, L.J., Fang, J.H and Yang, J.P. 2012. Nickel(II) and zinc(II) complexes of a pyridine ligand bearing a tetrathiafulvalene substituent. Transition Met Chem 1-5.

[6] Li, M.Y., Hu, P.Z., Xu, K.X., and Cai, L.H. 2005. Synthesis and Characterization of Transition Metal Complexes of Multidentate Ligands Containing a Pyridine Ring. Synthesis and Reactivity in Inorganic, MetalOrganic and Nano-Metal Chemistry 35: 333-338.

[7] Teng, F., Jiang, N., Wang, Z., Cui, Y and Wang, J. 2011. Synthesis, crystal structure and computational chemistry research of the zinc(II) complex: $\left[\mathrm{Zn}(\mathrm{pt})(\mathrm{Biim})_{2}\right]$. J. Serb. Chem. Soc. 77: 177-185.

[8] Montazerozohori, $\mathrm{M}$ and Sedighipoor, M. 2012. Synthesis, spectral identification, electrochemical behaviour and theoretical investigation of new zinc complexes of bis((E) 3-(2nitrophenyl)-2-propenal)propane-1,2 diimine. Spectrochimica Acta Part A: Molecular and Biomolecular Spectroscopy 96: 70-76. 